Reprod. Nutr. Dévelop., 1988, 28 (2 B), 375-385.

\title{
Possible homologies between photorefractoriness in sheep and birds : the effect of thyroidectomy on the length of the ewe's breeding season
}

\author{
T. J. NICHOLLS, B. K. FOLLETT, A. R. GOLDSMITH, H. PEARSON (*) \\ AFRC Group on Photoperiodism \& Reproduction, Department of Zoology and \\ (*) Department of Veterinary Surgery, \\ University of Bristol, Bristol BS8 1UG, United Kingdom.
}

Summary. Comparisons are drawn between the photoperiodically driven breeding cycles in "long-day" birds and "short-day" mammals, emphasizing the importance of photorefractoriness as a key regulator in the timing processes. It is argued that the two types of breeding cycle may not be so radically different as previously thought and, indeed the cycles may be strictly homologous. Evidence in support of this comes from the role of the thyroid glands in seasonality. In starlings and quail, thyroidectomy prevents refractoriness developing and the birds remain in breeding indefinitely under long days. If the processes underlying refractoriness are similar across species then thyroidectomy should greatly alter the ewe's breeding cycle. In two experiments, Welsh Mountain ewes were thyroidectomized in the summer during anoestrus and their subsequent periods of oestrus monitored under various daylengths. There was no effect of thyroidectomy on the time when oestrous cyclicity began in the Autumn but the onset of anoestrus was profoundly disrupted. All the ewes continued to cycle well beyond the end of the normal breeding season and a number have continued throughout the entire period of anoestrus.

Most of our work has focussed upon the control of seasonal reproduction in birds, and in this paper we would like to highlight some similarities between avian reproductive cycles and those of ungulates such as sheep. Although the evidence is not yet conclusive, it is our suspicion that strict physiological homologies may exist between many, perhaps all, aspects of the reproductive processes in birds and mammals and, as we shall try to show, "long-day " breeders like birds may have basic seasonal physiological changes that are much more similar to those of ungulates than is generally realised (review in Nicholls, Goldsmith and Dawson, 1988). Indeed, the hypothesis might extend to include some of the carnivores whose active reproductive periods span the shortest day. Our own efforts have concentrated upon species of birds from north temperate zones all of which show basically similar responses to changes in daylength, though in each case there are unique, superficial, variations in the speed, threshold and magnitude of the 
photoperiodic response which equip each species for its own ecological niche (recent reviews, Follett and Nicholls, 1984 ; Nicholls et al., 1988). One example is the European starling (Sturnus vulgaris) which has proved valuable as an experimental model because it has a particularly strong annual breeding cycle which is very dependent upon changes in photoperiod for its expression. As Figure 1 illustrates, starlings are reproductively active in March in the United Kingdom. At this time pituitary gonadotrophin secretion markedly increases, the gonads develop some 400 -fold to full size and the birds build nests and lay eggs. In April the young are hatched, are fed by the parents, and fledge during May. After a further brief period of parental care, the breeding season ends abruptly and the gonads of the adult birds regress rapidly. They remain quiescent, so far as can be seen superficially, until the following spring. At first sight, this pattern of seasonal reproduction is very different from that of Northern ungulates in which reproductive activity begins in the late autumn and ends in spring. However, as will be discussed below, we suspect that the differences are not as profound as they appear and we have gone so far as to suggest that the reproductive processes of all seasonally breeding higher vertebrates will eventually be seen to function according to a common plan (Nicholls et al., 1988).

FIG. 1. - Changes in testicular weight and plasma concentrations of $\mathrm{LH}$ and prolactin in male starlings trapped from the wild in calendar 1980. Each point represents the mean \pm SEM and the numbers of individuals are shown. From Dawson and Goldsmith (1982).

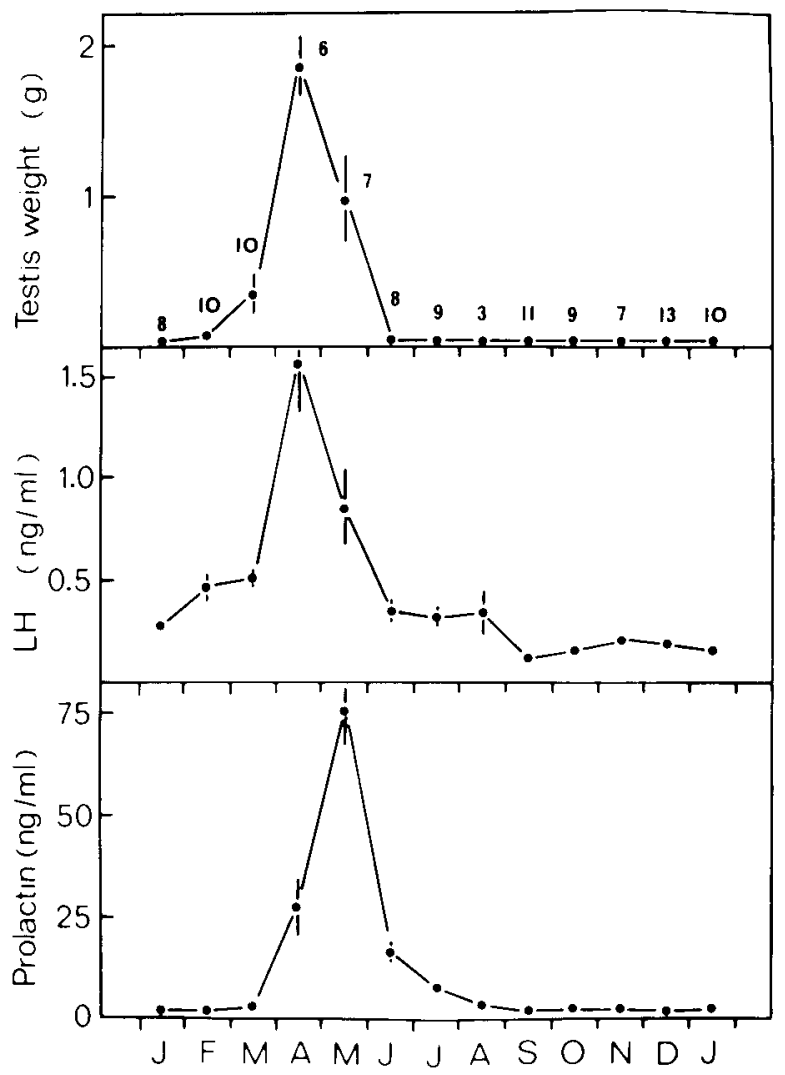


When starlings cease reproduction under natural conditions the peripheral reproductive system remains in a completely juvenile condition from late May until the following March (Dawson and Goldsmith, 1982). However, conclusions drawn only from the low levels of plasma gonadotrophins and the fully-regressed state of the gonads throughout this period are misleading. In fact, important changes are taking place and these are revealed if the starlings are gonadectomized (Dawson and Goldsmith, 1984). In such birds plasma gonadotrophin levels decrease abruptly as refractoriness develops in May, remain extremely low until midOctober but then increase markedly as refractoriness ends, and remain high until the following May when they decrease again (fig. 2). Clearly, the apparently long quiescent period in the intact bird consists of two separate phases marked by a sharp transition. From May until mid-October the hypothalamo-hypophysial system is quite inactive, even in the absence of inhibitory feedback from gonadal steroids; it then, apparently rather suddenly, becomes active, but, in intact animals, any increases in gonadotrophin secretion at this time are rapidly damped out by gonadal steroid secretion. This transition from suppression of the neurosecretory system during the refractory state by non-steroid-dependent processes to suppression by steroids is confirmed by several other observations. For example, plasma androgens rise very slightly in mid-October (Temple, 1974 ; Dawson, 1983) and active Leydig cells appear in the testes at this time (Lam and Farner, 1976 ; Storey, 1978). The bill colour of starlings, which is completely androgen-dependent, changes from black to yellow. Most importantly, primary changes are also observable within the hypothalamus. The content of gonadotrophin-releasing hormone $(\mathrm{GnRH})$ diminishes to exceedingly low levels in refractory birds but increases markedly at the transition point, as revealed either by direct radioimmunoassay or by immunocytochemistry (Dawson et al.,

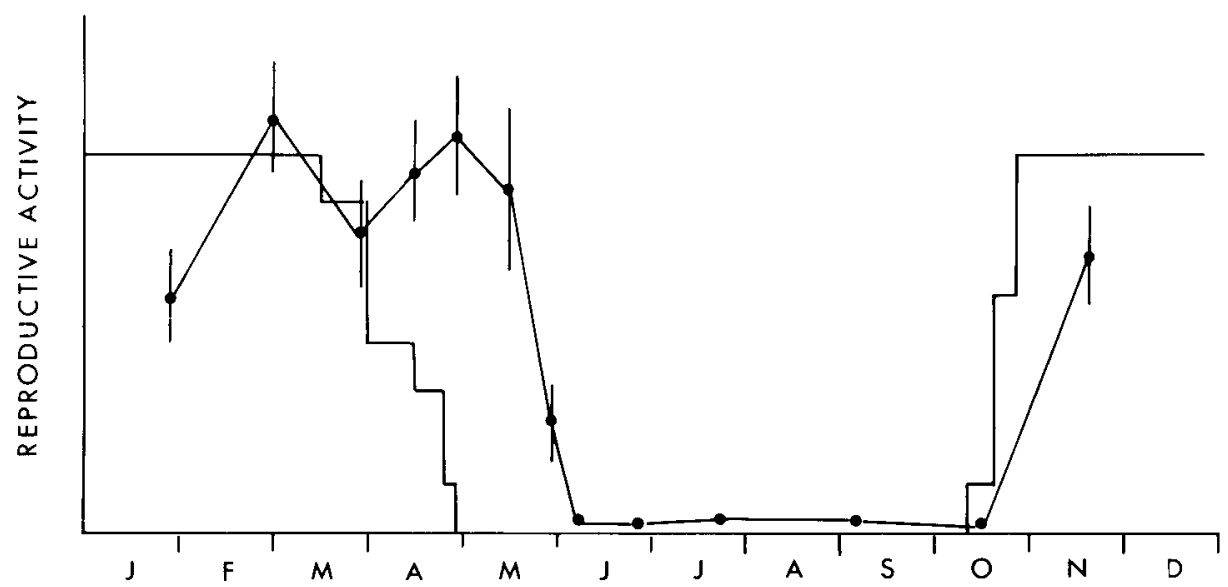

FIG. 2. - Seasonal reproductive patterns in a group of We/sh Mountain ewes (percentage of animals showing oestrous cycles) and a group of ovariectomized starlings (plasma LH levels) (• -- $\bullet$ ). In the birds, in the absence of gonadal steroids, the hypothalamo-pituitary system commences active secretion in late autumn, at much the same time as the sheep commence reproductive activity. 
1985a ; Foster et al., 1987). Such a reactivation of the hypothalamo-pituitarygonad axis is not confined to starlings but can be seen in many birds (e.g. mallards and teal, Jallageas, Tamisier and Assenmacher, 1978 ; Rooks, Lincoln et al., 1980). Indeed, it probably manifests itself widely under natural conditions and Morley (1943) listed 63 species of British birds which show " autumnal sexuality ".

In terms, therefore, of activity of the reproductive system, as judged by hypothalamic $\mathrm{GnRH}$ content or gonadotrophin secretion, the cycle in the gonadectomized starling now begins to look very much like that of a ewe (fig. 2). In summer the reproductive system is switched off in both species but in late autumn it switches on again and this continues until the following late spring. It could be said that birds transform themselves into spring breeders by the agency of gonadal steroid feedback which inhibits reproduction in late autumn and winter. In our flock of Welsh Mountain ewes oestrous cycling frequently continues in non-pregnant animals until March and in some cases until April. The reproductive system of starlings switches off in May. These differences in timing of reproductive shutdown (or refractoriness) are not great and we have felt it worth asking whether the underlying processes may not be similar in both birds and mammals.

\section{OUTSIDE

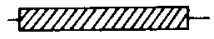 \\ -}

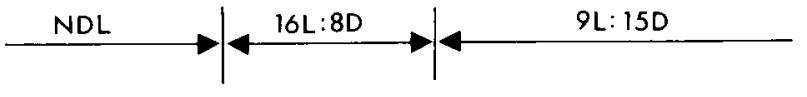

INTACT
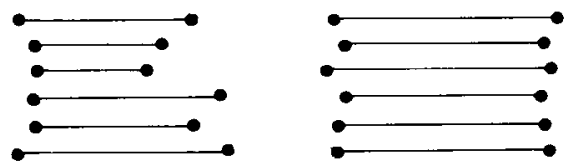

THYROIDEX.
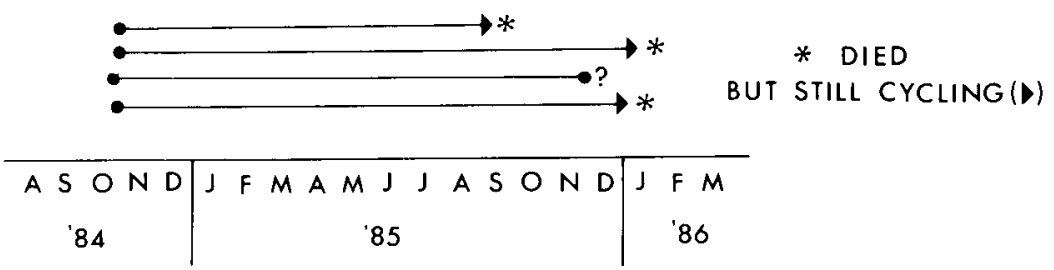

FIG. 3. - Duration of oestrous cyclicity (as judged when plasma progesterone was $>0.5 \mathrm{ng} / \mathrm{ml}$ ) in intact and thyroidectomized ewes in 1984-1986. The thyroid glands were removed surgically in early August 1984. The solid dots show the onset and offset of the oestrous cycles. Solid arrows indicate the ewe was still cycling when she was killed. The hatched bars above the figure indicate the natural breeding season in a separate group of Welsh Mountain ewes. NDL, natural daylight.

Some differences are immediately apparent, of course. First, the reproductive shutdown in birds is completely dependent upon exposure to long daylengths. For example, starlings exposed to daily photoperiods of less than $12 \mathrm{~h}$ become reproductively mature, albeit fairly slowly, but then remain in this state indefinitely (Hamner, 1971; Goldsmith and Nicholls, 1984). Exposure of such birds to a few 
long days at any time can then switch off the reproductive system a few weeks later (Dawson et al., 1985b). In sheep such a complete photoperiodic dependence does not exist for several studies have shown convincingly that anoestrus will occur, usually at about the normal time, when the sheep are maintained under constant daylengths (e.g. Thwaites, 1965 ; Ducker et al., 1973). However, we would like to suggest that this observation does not preclude the possibility that the internal processes leading to reproductive shut down in the two types of animal may be identical ; merely it shows that in the starling such processes are absolutely dependent upon the appropriate photoperiodic stimulus whereas in the sheep the dependence is facultative. Long daylengths may accelerate the onset of reproductive inactivity in sheep (e.g. Yeates, 1949) but the process can occur in their absence. Facultative and obligatory photoperiodic dependencies like these are well documented in plants but do not lead botanists to postulate fundamentally different underlying internal processes (Vince-Prue, 1975).

It does seems likely that in all seasonally-reproductive vertebrates, some component of the internal environment induced by reproductive inactivity somehow pre-disposes the reproductive system to become active, and that after a period of activity the system is then pre-disposed to switch off. In species where these phases are not absolutely dependent upon a " correct " photoperiod (or in situations where intermediate or "neutral " daylengths are maintained) the tendency to switch between phases of reproductive activity and inactivity may give rise to endogenous cycles of reproduction, often referred to as " circannual rhythms » (e.g. sheep, Karsch, Robinson, and Woodfill, 1987 ; ground squirrels, Kenagy, 1981 ; starlings on 12L : 12D, Gwinner, 1981). We wonder if it might be extremely valuable to undertake experimental studies to determine if any known facets of reproductive activity, for example, the specific hormonal environment characteristic of that state, can predispose an animal to enter the alternate phase of reproductive inactivity.

One feature of reproductive shutdown in starlings and sheep, admittedly still poorly understood, which reinforced our suspicion that the processes involved may be homologous in the two animals is their dependence upon thyroid hormones. When starlings are thyroidectomized and then exposed to long dayiengths gonadotrophin secretion and consequent gonadal maturation are virtually unaffected but the reproductive system is unable to switch off (as it does in intact control birds in about 50 days) (Wieselthier and van Tienhoven, 1972 ; Goldsmith and Nicholls, 1984 ; Goldsmith, Nicholls and Plowman, 1985). We have kept such thyroidectomized birds under long daylengths for several years and they remain in a state of permanent sexual maturity. A single injection of $50 \mu \mathrm{g}$ of thyroxine permits full reproductive shut-down which begins 15 days or so after the thyroxine and is complete in 40-50 days (Goldsmith, Nicholls and Plowman, 1988). We do not yet know why thyroxine is necessary for the expression of long-day induced reproductive switch-off in these birds, but even in the absence of such specific knowledge, thyroxine dependence is clearly diagnostic of the switch-off process. Accordingly, we reasoned that if homologous processes controlled the onset of anoestrus in sheep, they might also be predicted to be dependent upon thyroid hormones. 
This has been tested in two separate experiments carried out over the past three years. In both, groups of Welsh Mountain ewes were thyroidectomized at the end of July, held on natural daylengths until oestrous cycles had begun and then switched to fixed photoperiods. Circulating progesterone was measured in blood samples collected weekly or twice weekly. Figure 3 shows the results from the first experiment begun in the summer of 1984 and Figure 4 shows data from a larger experiment begun a year ago. Clearly, thyroidectomy did not affect the onset of oestrus in early October but it delayed or abolished the switch off. In the first experiment all four thyroidectomized ewes continued to show oestrous cyclicity, as judged from circulating progesterone, throughout the entire period when the control ewes were in anoestrus. After about a year three of the ewes began to show signs of general debilitation and they were killed. The fourth ewe stopped cycling after 13 months. The experiment was repeated (with a constant photoperiod of 12L : $12 \mathrm{D}$ rather than transfers between long and short days) in $1986 / 87$ with essentially the same results (fig. 4). The mean date of onset was not different in the two groups (controls, day $289 \pm 2(14)$; thyroidectomized ewes, $284 \pm 3(10), P>0.2$ ) but despite the more severe problems with debilitation in this experiment the effects in delaying anoestrus were again clearcut. The duration of the oestrous period in the controls was $97.8 \pm 8.5(14)$ days and the mean date of anoestrus was days $23 \pm 4.9$ (14) of 1987 . On that date all ten of the thyroidectomized ewes were still cycling. Of the six sheep terminated between March and May all were cycling up to the point when they were killed. The other four are still alive (and well) and as of August 1987 were cycling regularly. Three

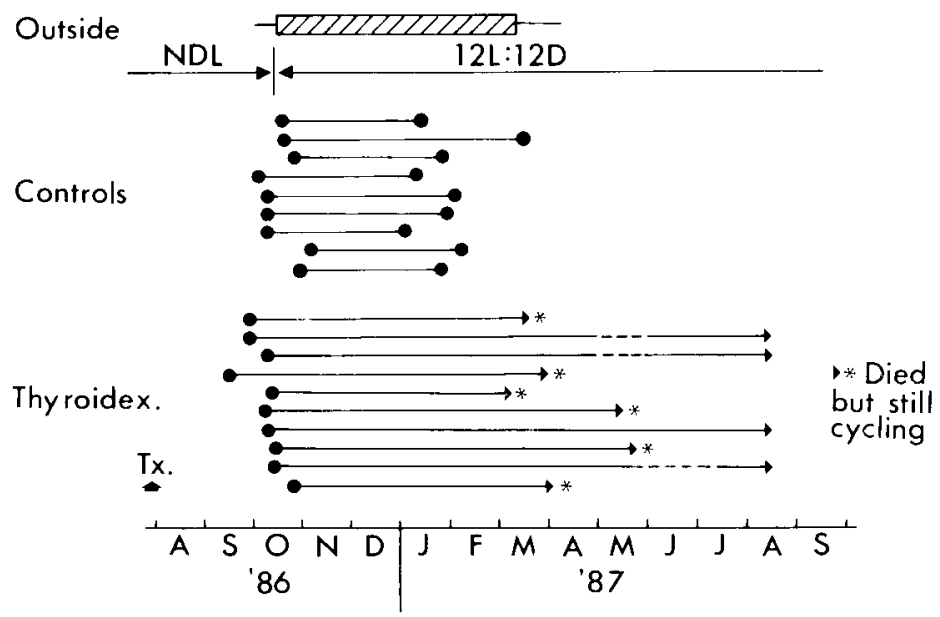

FIG. 4. - Comparison of duration of reproductive periods (plasma progesterone $>0.5 \mathrm{ng} / \mathrm{ml}$ ) of intact control and thyroidectomized We/sh Mountain Ewes. From mid-October 1986 all animals were held indoors on $12 \mathrm{~L}: 12 \mathrm{D}$. Thyroidectomy was carried out in late July 1986 . The hatched bar at top shows, for reference, the reproductive period $( \pm S E M)$ of ten ewes of this breed kept outdoor and subjected to natural daylength changes. Intact animals kept on $12 \mathrm{~h}$ daylengths have a rather short breeding season, but anoestrus is markedly delayed or prevented in the thyroidectomized group. 
seemed to stop briefly in the summer but then began cycling again spontaneously.

In one instance we have compared levels of free plasma thyroxine in thyroidectomized and control ewes while they are cycling in late autumn. The values were $13.9 \pm 0.9 \mathrm{pmol} / \mathrm{l}$ for the control animals $(\mathrm{n}=10$ ) while thyroxine was not detectable $(<1 \mathrm{pmol} / \mathrm{l})$ in the plasma of the thyroidectomized group $(n=5)$. Such measurements have not yet been extended to monitor thyroxine levels over long periods during the course of experiments, but we have made such observations for plasma TSH (fig. 5). As expected, circulating concentrations of this hormone are markedly elevated soon after thyroidectomy and remain high and constant over the period of observation.

\section{Effect of thyroidectomy on TSH secretion}

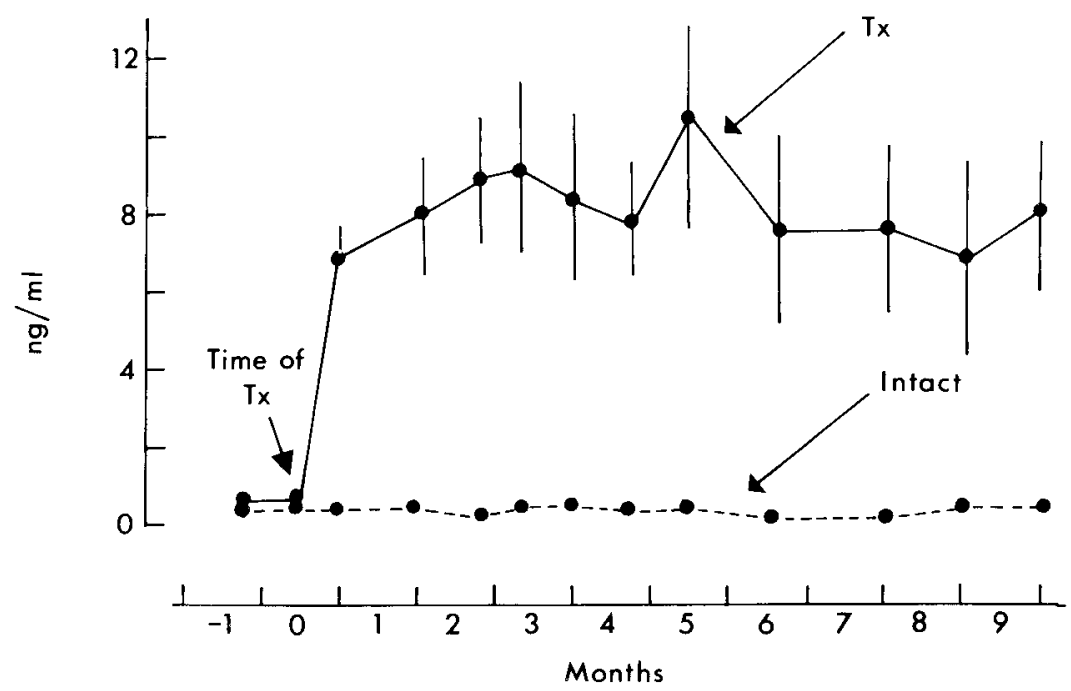

FIG. 5. - Plasma TSH levels (as measured by an homologous ovine assay) in the intact and thyroidectomized (Tx) Welsh Mountain ewes shown in Fig. 4. After removal of the thyroid glands $\mathrm{TSH}$ concentrations are markedly raised and remain high.

In intact ewes subjected to natural daylength changes, there are no significant annual variations in plasma TSH which can be correlated with changes in reproductive status (fig. 6). This has also been reported by Fraser and McNeilly (1982).

We suspect (but cannot yet prove) that in sheep, as in starlings, seasonal reproductive processes are not induced by variations in the activity of the pituitary/thyroid axis but thyroxine must be available to permit the switching off processes to develop within the brain. We do not know why an absence of thyroxine prevent the onset of reproductive quiescence in birds and mammals but see Dawson et al. (1985a) and Goldsmith et al. (1988). In a single experiment 
conducted in April, however, we compared the daily plasma melatonin patterns in our intact and thyroidectomized ewes living on 12L : 12D. The thyroidectomized animals were still reproductively active and the controls were in anoestrus but the plasma melatonin patterns, at least in terms of the duration of elevated night levels of the hormone, appear similar in the two groups (fig. 7). Thyroidectomy

Annual cycle in TSH

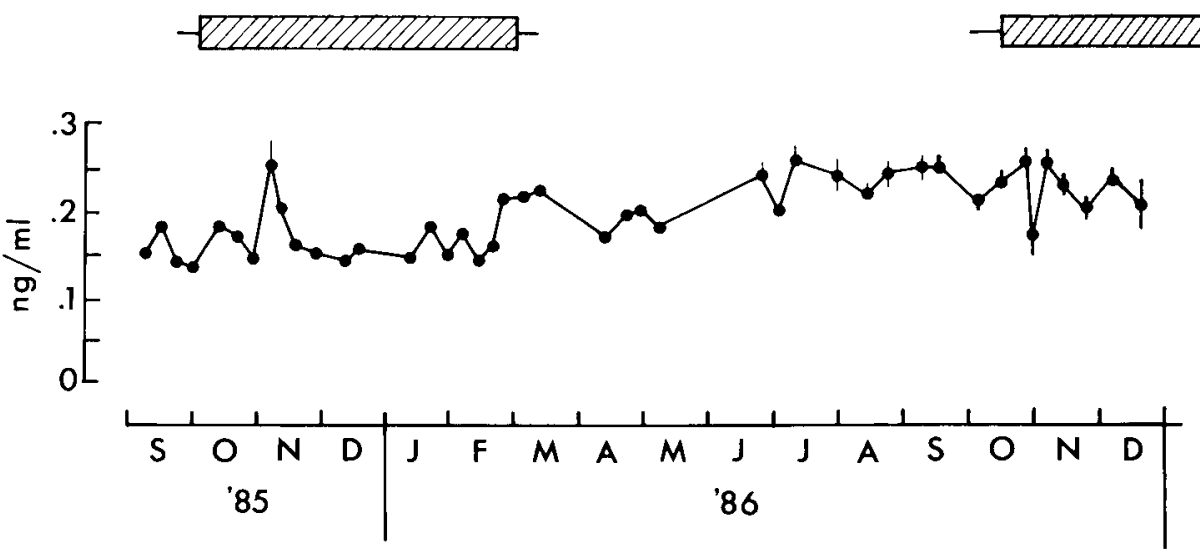

FIG. 6. - Seasonal plasma levels of TSH in a group of 10 intact Welsh Mountain ewes subjected to natural changes in daylength. Concentrations change very little throughout the year. Hatched bars show the periods of oestrous cyclicity in this very seasonally-reproductive breed. The SEM is shown where it is greater than the area covered by the solid dot.

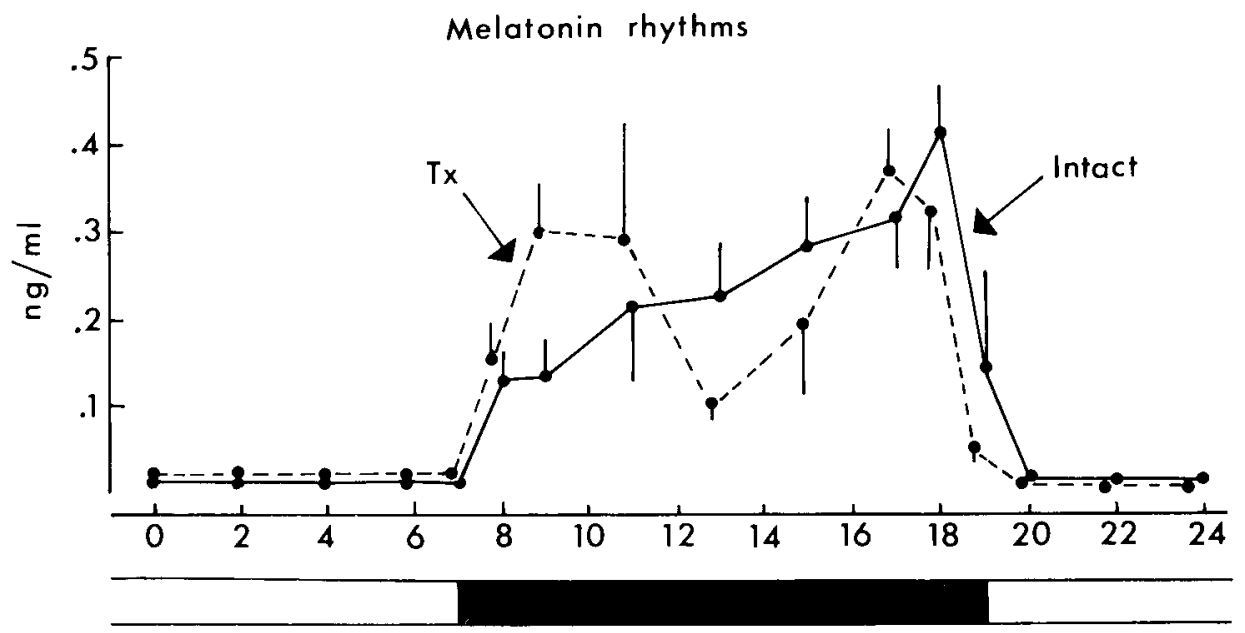

Hours

FIG. 7. - Similar patterns of plasma melatonin in five thyroidectomized and five intact Welsh Mountain ewes held on 12L:12D (ewes as in fig. 4). The dark bar indicates when lights were off. The measurements were made during a single $24 \mathrm{~h}$ period in April 1987 when the intact ewes were in anoestrus and the thyroidectomized animals were still reproductively active. Each point represents mean value \pm SEM 
does not appear to alter pineal melatonin secretion in a way which could explain prolongation of reproductive activity and this is consistent with other work showing that refractoriness develops in sheep whilst melatonin secretion is unaltered (e.g. Malpaux et al., 1987).

Obviously, thyroidectomy as a means of artificially extending the breeding season can have no direct commercial application but experiments are presently underway in which thyroid function is being disabled temporarily at key times of the year. Our interest, of course, is more basic since we wish to learn if the photoperiodic cycles of "short-day breeders " and "long-day breeders " are fundamentally different, as we have traditionnally believed, or if the differences are really quite slight and represent variations on a common set of underlying processes. So far, the evidence from thyroidectomy and from other photoperiodic experiments (Nicholls, Jackson and Follett, 1988) is supportive of the latter view but we freely accept that many more critical tests are required. It is encouraging that other species are now being investigated, including the mink (Jacquet et al., 1986).

Colloquium on "Neuroendocrine mechanisms and light control of reproduction in domestic mammals " I.N.R.A., Nouzilly, 17-18 September 1987.

Acknowledgements. - We thank Dr A. Symons and his colleagues (University of Surrey, U.K.) for conducting the plasma melatonin assays and $\mathrm{Mr} \mathrm{S}$. Kestin and the farm staff at the AFRC's Institute of Food Research, Bristol for careful husbandry of the sheep.

Résumé. Homologie possible entre la photoréfraction chez le mouton et chez l'oiseau : effet de la thyroïdectomie sur la durée de la saison de reproduction chez la brebis.

Des comparaisons sont effectuées entre les cycles de reproduction entraînés par la photopériode par les jours longs chez les oiseaux et par les jours courts chez les mammifères, faisant ressortir l'importance de la photoréfraction comme régulateur " clé " des processus de mesure du temps. Des arguments sont présentés montrant que ces deux types de cycle de reproduction peuvent ne pas être aussi radicalement différents que supposé auparavant, et même que ces cycles peuvent être strictement comparables.

Le rôle de la glande thyroïde sur la saisonnalité en apporte l'évidence. Chez l'étourneau et chez la caille, la thyrö̈dectomie empêche la photoréfraction de se développer et les oiseaux restent en reproduction indéfiniment sous « jours longs". Si les processus qui commandent la photoréfraction sont identiques entre les espèces, la thyroïdectomie devrait alors altérer fortement le cycle de reproduction de la brebis. Dans deux expériences, des brebis Welsh Mountain ont été thyroïdectomisées en été au cours de l'anoestrus et leurs périodes d'oestrus enregistrées sous diverses durées du jour. La thyroïdectomie n'a pas eu d'effet sur le moment où les cycles oestriens débutent en automne mais sur le début de l'anoestrus qui était profondément modifié. Toutes les brebis ont présenté des cycles bien au-delà de la fin de la saison normale de reproduction et certaines ont été cycliques pendant toute la période normale d'anoestrus.

\section{References}

DAWSON A., 1983. Plasma gonadal steroid levels in wild starlings (Sturnus vulgaris) during the annual cycle and in relation to the stages of breeding. Gen. comp. Endocr., 49, 286-294.

DAWSON A., FOLLETT B. K., GOLDSMITH A. R., NICHOLLS T. J., 1985a. Hypothalamic gonadotropin-releasing hormone and pituitary and plasma $\mathrm{FSH}$ and prolactin during 
photostimulation and photorefractoriness in intact and thyroidectomized starlings /Sturnus vulgaris), 105, 71-77.

DAWSON A., GOLDSMITH A. R., 1982. Prolactin and gonadotrophin secretion in wild starlings (Sturnus vulgaris) during the annual cycle and in relation to nesting, incubation and rearing young. Gen. comp. Endocr., 48, 213-221.

DAWSON A., GOLDSMITH A. R., 1984. Effects of gonadectomy on seasonal changes in plasma LH and prolactin concentrations in male and female starlings (Sturnus vulgaris). J. Endocr., 100. 213-218.

DAWSON A., GOLDSMITH A. R., NICHOLLS T. J., 1985b. Development of photorefractoriness in intact and castrated male starlings (Sturnus vulgaris) exposed to different periods of long-day lengths. Physiol. Zool., 58, 253-261.

DUCKER M. J., BOWMAN J. C., TEMPLE A., 1973. The effect of constant photoperiod on the expression of oestrus in the ewe. J. Reprod. Fertil., Suppl. 19, 143-150.

FOLLETT B. K., NICHOLLS T. J., 1984. Photorefractoriness in Japanese quail: possible involvement of the thyroid gland. J. exp. Zool., 232, 573-580.

FOSTER R. G., PLOWMAN G., GOLDSMITH A. R., FOLLETT B. K., 1987. Immunohistochemical demonstration of marked changes in the LHRH system of photosensitive and photorefractory European starlings (Sturnus vulgaris). J. Endocr. (in press).

FRASER H. M., MCNEILLY A. S., 1982. Effect of chronic immunoneutralization of thyrotropinreleasing hormone on the hypothalamic-pituitary-thyroid axis, prolactin, and reproductive function in the ewe. Endocrinology, 111, 1964-1973.

GOLDSMITH A. R., NICHOLLS T. J., 1984. Thyroidectomy prevents the development of photorefractoriness and the associated rise in plasma prolactin in starlings. Gen. comp. Endocr., 54, 256-263.

GOLDSMITH A. R., NICHOLLS T. J., PLOWMAN G., 1985. Thyroxine treatment facilitates prolactin secretion and induces a state of photorefractoriness in thyroidectomized starlings. $J$. Endocr., 104, 99-103.

GOLDSMITH A. R., NICHOLLS T. J., PLOWMAN G., 1988. Induction of photorefractoriness in thyroidectomized starlings exposed to long but not to short daily photoperiods, by a single injection of thyroxine. J. Endocr., (submitted).

GWINNER E., 1981. Circannual rhythms : their dependence on the circadian system, 153-170. In Biological clocks in seasonal reproductive cycles. Eds B. K. \& D. E. FOLLETT, Scientechnica, Bristol.

HAMNER W. M., 1971. On seeking an alternative to the endogenous reproductive rhythm hypothesis in birds, 448-461. In Biochronometry, Ed. M. MENAKER. Nat. Acad. Sci., Washington DC.

JACQUET J.-M., COUTANT C., MAUREL D., BOISSIN-AGASSE L., BOISSIN J., 1986. Influence de la thyrö̈dectomie sur les variations, au cours du printemps et de l'été, de l'activité testiculaire et de la prolactinémie chez le Vison. C. R. Acad. Sci. Paris, 303, 367-370.

JALLAGEAS M., TAMISIER A., ASSENMACHER I., 1978. A comparative study of the annual cycles in sexual and thyroid function in male Peking ducks (Anas platyrhynchus) and teal (Anas crecca). Gen. comp. Endocr., 36, 201-210.

KARSCH F. J., ROBINSON J. E., WOODFILL C. J. I., 1987. Existence of an endogenous reproductive rhythm in the ewe. Proc. 69th ann. Meet. Endocr. Soc., Abstr. 262, p. 86.

KENAGY G. J., 1981. Endogenous annual rhythm of reproductive function in the non-hibernating desert ground squirrel Ammospermophilus leucurus. J. comp. Physiol., 142, 251-258.

LAM F., FARNER D. S., 1976. The ultrastructure of the cells of Leydig in the white-crowned sparrow in relation to plasma levels of luteinizing hormone and testosterone. Cell Tiss. Res., 169, 93-109.

LINCOLN G. A., RACEY P. A., SHARP P. J., KLANDORF H., 1980. Endocrine changes associated with spring and autumn sexuality of the rook, Corvus frugilegus. J. Zool. Lond., 190, 137153.

MALPAUX B., ROBINSON J. E., BROWN M. B., KARSCH F. J., 1987. Reproductive refractoriness of the ewe to inductive photoperiod is not caused by inappropriate secretion of melatonin. Biol. Reprod,, 36, 1333-1341.

MORLEY A., 1943. Sexual behaviour in British birds from October to January. Ibis, 85, 132-158. 
NICHOLLS T. J., GOLDSMITH A. R., DAWSON A., 1988. Photorefractoriness in birds and comparison with mammals. Physiol. Rev., in press.

NICHOLLS T. J., JACKSON G. L., FOLLETT B. K., 1988. Reproductive refractoriness in the Welsh Mountain ewe induced by short day-lengths can be overriden by exposure to even shorter photoperiods. Biol. Reprod., (submitted).

STOREY C. R., 1978. An investigation into the physiological basis of avian reproductive photorefractoriness. Ph. D. Thes., Univ. London.

TEMPLE S. A., 1974. Plasma testosterone titers during the annual reproductive cycle of starlings (Sturnus vulgaris). Gen. comp. Endocr., 22, 470-479.

THWAITES C. J., 1965. Photoperiodic control of breeding activity in the Southdown ewe with particular reference to the effect of an equatorial light regime. J. agric. Sci., 65, 57-64.

VINCE-PRUE D., 1975. Photoperiodism in plants. pp. 444. McGraw Hill, London.

WIESELTHIER A. S., VAN TIENHOVEN A., 1972. The effect of thyroidectomy on testicular size and on the photorefractory period in the starling (Sturnus vulgaris). J. exp. Zool., 179, 331-338.

YEATES N. T. M., 1949. The breeding season of the sheep with particular reference to modification by artificial means using light. J. agric. Sci., 39, 1-43. 